\section{Ten-year evaluation of a Neonatal Screening Program for Congenital Adrenal Hyperplasia}

\author{
Avaliação de dez anos de um Programa de Triagem \\ Neonatal para Hiperplasia Adrenal Congênita
}

Marilza Leal Nascimento 1,2, Anísia Nhelety Baptista Cristiano², Tatiane de Campos $^{1}$, Masanao Ohira ${ }^{2}$, Edson Cechinel', Genoir Simoni', Juliana van de Sande Lee', Rose Marie Muller Linhares', Paulo Cesar Alves da Silva'
1 Hospital Infantil Joana de Gusmão (HIJG), Endocrine Pediatric Department, Florianópolis, SC, Brazil 2 Universidade Federal de Santa Catarina (UFSC), Florianópolis, SC, Brazil when the first sample for 17-hydroxyprogesterone (17OHP) measurement was collected, levels of $170 \mathrm{HP}$, mean age at treatment onset and main clinical manifestations. Results: The NSP-SES/ $\mathrm{SC}$ covered $89 \%$ of the live newborns in the State. It diagnosed 50 cases of $\mathrm{CAH}$, yielding an incidence of 1:14,967. Mean age at collection of the first sample was 7.3 days and mean level of $170 H P$ was $152.9 \mathrm{ng} / \mathrm{mL}$. The most frequent manifestations were virilized genitalia with nonpalpable gonads, clitoromegaly and genital hyperpigmentation. In three girls, the genre established at birth was incorrect. The salt-wasting form was present in $74 \%$ of the cases. There was no occurrence of shock or death. Mean age at treatment onset in the salt-wasting form was 17.4 days compared with 54.9 days in those without the salt-wasting form of the disease. All children were treated with hydrocortisone, and those with salt-wasting $\mathrm{CAH}$ were also treated with fludrocortisone. Conclusions: The incidence of CAH was 1 case to 14,967 live newborns. Collection of the first sample occurred outside the recommended time, resulting in delays in treatment onset. Arq Bras Endocrinol Metab. 2014;58(7):765-71

\section{Keywords}

Congenital adrenal hyperplasia; neonatal screening; 21-hydroxylase deficiency; 17-hydroxyprogesterone

\section{RESUMO}

Objetivo: Avaliar o Programa de Triagem Neonatal da Secretaria de Estado da Saúde de Santa Catarina (PTN-SES/SC) em relação à hiperplasia adrenal congênita (HAC) e fornecer subsídios que possibilitem seu aperfeiçoamento. Sujeitos e métodos: Estudo descritivo e retrospectivo de 748.395 crianças triadas no período de janeiro de 2001 a dezembro de 2010, sendo analisados a cobertura do PTN-SES/SC, a prevalência da HAC, a idade na coleta da primeira amostra para 17-hidroxiprogesterona (170HP), os níveis de $170 \mathrm{HP}$, a idade média de início de tratamento e as principais manifestações clínicas. Resultados: A cobertura do PTN-SES/SC foi de 89\% dos recém-nascidos vivos no Estado. Foram diagnosticados 50 casos de HAC, com incidência de 1:14.967. A média de idade na coleta da primeira amostra foi de 7,3 dias e a de $170 \mathrm{HP}$, de 152,9 ng/mL. As manifestações mais frequentes foram genitália virilizada sem gônadas palpáveis, clitoromegalia e hiperpigmentação genital. Em três meninas ocorreu erro no estabelecimento de gênero ao nascimento. A forma perdedora de sal foi encontrada em $74 \%$ dos casos. Nenhum caso de choque ou óbito foi verificado. A média de idade no início do tratamento nos perdedores de sal foi de 17,4 dias e nos não perdedores, de 54,9 dias. Todas as crianças foram tratadas com hidrocortisona e, nos casos com a forma perdedora de sal, associou-se fludrocortisona. Conclusões: A incidência de HAC foi de 1 caso para 14.967 recém-nascidos vivos. A coleta da primeira amostra ainda ocorreu fora do tempo preconizado, acarretando atraso no início do tratamento. Arq Bras Endocrinol Metab. 2014;58(7):765-71

\section{Descritores}

Hiperplasia adrenal congênita; triagem neonatal; deficiência 21-hidroxilase; 17-hidroxiprogesterona
Correspondência para: Marilza Leal Nascimento Rua Rui Barbosa, 152 88025-301 - Florianópolis, SC, Brazil marilzalealn@gmail.com

Recebido em 24/Fev/2014 Aceito em 17/Jun/2014

DOI: 10.1590/0004-2730000003310 


\section{INTRODUCTION}

$\mathrm{D}$ eficiency of the 21-hydroxylase $(21 \mathrm{OH})$ enzyme as a result of mutations in the CYP2IA2 gene (chromosome 6) is the most common form of congenital adrenal hyperplasia $(\mathrm{CAH})(\mathrm{l})$. This deficiency hinders the production of cortisol in sufficient amounts to inhibit secretion of the adrenocorticotropic hormone $(\mathrm{ACTH})$ by the pituitary, resulting in accumulation of the precursor 17-hydroxyprogesterone (17OHP) and increase in synthesis of adrenal androgens (2).

Overall, the disease affects $1: 10.000-15.000$ newborns worldwide. The degree with which each mutation compromises the enzymatic activity is strongly associated with the severity of the clinical manifestations of the disorder (3). In the $21 \mathrm{OH}$ deficiency, there is an spectrum of clinical manifestations that can be divided into three forms: classic form (salt-wasting, with compromised aldosterone synthesis), classic simple-virilizing (non-salt wasting) form, and nonclassic form $(3,4)$. In the classic form, female newborns present several degrees of virilization of the external genitalia at birth. In males, the external genitalia undergoes normal differentiation, but enlarged phallus may be present. The salt-wasting form is present in $75 \%$ of the cases and manifests early, generally after the second week, affecting both sexes. When present, adrenal crisis is characterized by volume depletion, dehydration, hypotension, hyponatremia and hypokalemia which can result in death if not treated (5). The nonclassic form manifests in both genders in the postnatal period with premature pubarche, clitoromegaly or enlarged penis, increase in growth rate with advance in bone age, and eventually, decrease in the estimated final height $(6,7)$.

Since CAH is an autosomal recessive disease, an even distribution between both genders is expected. However, when based on a clinical diagnosis, girls predominate over boys (4:1) since in them, the changes in the external genitalia make the diagnosis more evident. In contrast, boys with the salt-wasting form of the disease generally die without a diagnosis (8).

The need to prevent an adrenal crisis and its consequences and avoid psychological damage from an incorrect gender diagnosis in female newborns lead to a search for methods to screen this pathology in neonates (9).

The main aims of the screening are: to detect severe cases of the disease in order to prevent cerebral damage and death through presymptomatic treatment and prevent in virilized girls an incorrect gender identification on civil registration, or even, reduce the time that the register remains incorrect $(10,11)$.
A reliable and valid screening test for $\mathrm{CAH}$ using a blotter impregnated with a blood sample obtained from the heel of the newborn became first available in 1977 and allowed establishment of an elevated blood level of $17 \mathrm{OHP}$ as an indication of $\mathrm{CAH}$. This technique was initially developed in Alaska and used radioimmunoassay developed by Pang and cols. (12).

After that, the method to screen $\mathrm{CAH}$ at birth was systematically introduced in several regions of the world. The subsequent development of methods for direct determination of $17 \mathrm{OHP}$ rendered the test faster and simpler and promoted the beginning of new screening programs. Strategies to increase trust in the screening are still under development worldwide (5).

Since October 2000 in Santa Catarina, neonatal screening for $\mathrm{CAH}$ became part of a statewide program, rendering the State the first in Brazil to conduct this type of screening.

This study aims at evaluating the Neonatal Screening Program (NSP) for CAH of the Department of Health of the State of Santa Catarina (Secretaria de Estado da Saúde de Santa Catarina, SES/SC), between January 2001 and December 2010, providing information to allow improvement of the program. It also aimed at describing clinical and laboratorial features of children diagnosed with $\mathrm{CAH}$, allowing a better knowledge of these features in this population.

\section{SUBJECTS AND METHODS}

This study was conducted at the Department of Neonatal Analyses of the Central Laboratory of Public Health of Santa Catarina (Laboratório Central de Saude Pública de Santa Catarina, LACEN/SES), a reference center in neonatal screening, located in the Endocrine Pediatric Department (Serviço de Endocrinologia Pediátrica - SEP) of Joana de Gusmão Infant Hospital (Hospital Infantil Joana de Gusmão- HIJG) in Florianópolis, Santa Catarina, Brazil. We included all newborns screened for CAH by the NSP-SES/SC program between January 2001 and December 2010.

Samples for screening were obtained by collection of capillary blood in a special filter paper $\left(\right.$ Fitec $^{\circledR}$, thickness $2.24 \mathrm{~mm}$, grammage $105-110 \mathrm{~g} / \mathrm{m}^{2}$, linear, $100 \%$ cotton - S \& S 903) by puncturing the heel of the newborns in hospitals and health centers in all municipalities in Santa Catarina. Samples were sent to LACEN/ SES by mail, hand or mail pouch. Serum $17 \mathrm{OHP}$ levels were measured by time-resolved fluoroimmunoassay 
using the kit AutoDELFIA ${ }^{\circledR}$ neonatal 17OHP (B015112) until September 2009 and, after that, with the kit $\mathrm{GSP}^{\circledR}$ neonatal $17 \mathrm{OHP}$.

The cutoff values for 17OHP were based on birth weight. The approach adopted by the program before and after the change in screening kits is shown in table 1.

Table 1. Cutoff values according to birth weight and approach adopted by the neonatal screening program for congenital adrenal hyperplasia (CAH) in Santa Catarina

\begin{tabular}{ccc}
\hline Weight range & $\begin{array}{c}\text { Reference value to } \\
\text { recall for a second } \\
\text { sample } \mathbf{( n g / m L})\end{array}$ & $\begin{array}{c}\text { Risk value - urgent } \\
\text { medical evaluation } \\
\text { (ng/mL) }\end{array}$ \\
\hline From October 2000 to September 3, $2009\left(\right.$ Kit AutoDELFIA $\left.^{\circledR}\right)$ \\
$\geq 2,500 \mathrm{~g}$ & 9.9 to 30 & $>30$ \\
$<2,500 \mathrm{~g}$ & 19.8 to 40 & $>40$ \\
After September 4, 2009 (Kit GSP $\left.{ }^{\circledR}\right)$ & $>21$ \\
$\geq 2,250 \mathrm{~g}$ & 14 to 21 & $>41$ \\
$1,250-2,249 \mathrm{~g}$ & 33 to 41 & $>73$ \\
$<1,250 \mathrm{~g}$ & 56 to 73 & \\
\hline
\end{tabular}

When levels of 17OHP were above the upper cutoff value, the measurements were repeated twice on the first collected sample. If levels of $17 \mathrm{OHP}$ were confirmed to be abnormal, children were then referred for clinical and laboratory evaluation at SEP-HIJG. Laboratory evaluation included measurement of serum 17OHP (radioimmunoassay), androstenedione ( $\mathrm{ra}$ dioimmunoassay), testosterone (chemiluminescence), sodium (spectophotometry), potassium (spectrophotometry) and karyotype analysis in children with ambiguous genitalia. The reference values of these tests are summarized in table 2 .

We graded the external genitalia in female patients using the scale developed by Prader (13). When the diagnosis of $\mathrm{CAH}$ was suspected, treatment was started immediately on the first medical evaluation with hydrocortisone 10 to $25 \mathrm{mg} / \mathrm{m}^{2} /$ day (14). After the re- sults of the serum tests were obtained and 17OHP was confirmed to be elevated, treatment was maintained. We considered children with serum sodium below $132 \mathrm{mEq} / 1$ and/or serum potassium higher than 5.0 $\mathrm{mEq} / \mathrm{l}$ as having the salt-wasting form of $\mathrm{CAH}$ (15). In this situation, we added to the treatment oral fludrocortisone 0.1 to $0.2 \mathrm{mg}$ a day. We used an ion-selective electrode to measure electrolytes and repeated the measurement to confirm when the result was abnormal.

We retrieved data on the number of live births in the State from the database of the Brazilian Integrated Health Care System (Banco de Dados do Sistema Único de Sauide, Datasus) (16). The geographical origin of the patients was classified according to the mesoregions of Santa Catarina determined by the Brazilian Institute of Geography and Statistic (Instituto Brasileiro de Geografia e Estatística, IBGE) (17).

We analyzed the following variables: number of children screened; age at screening; 17OHP level on the first measurement and, if applicable, on the second measurement; elapsed time between the first 17OHP measurement and the first appointment (time to track, refer for medical evaluation and evaluate the child); geographical origin; gender; birth weight; levels of 17OHP, testosterone, androstenedione, sodium and potassium on diagnosis confirmation; karyotype; clinical manifestations on the first appointment; stage of development according to the Prader scale; age of the child on the first appointment and on treatment onset.

The study protocol was approved by the Ethics Committee for Research on Humans of HIJG as number $002 / 2011$ and received the decision number 005 $\mathrm{B} / 2011$.

To describe the results, we used absolute values of frequency, relative frequency, mean \pm standard deviation (SD), median, minimum and maximum. Student's

Table 2. Laboratory results in children with salt-wasting and simple-virilizing CAH. Data expressed as means \pm standard deviations

\begin{tabular}{lcccccc}
\hline \multicolumn{1}{c}{ Variables } & $\begin{array}{c}\text { Salt wasting } \\
(\mathbf{n = 3 7 )}\end{array}$ & $\begin{array}{c}\text { Confidence } \\
\text { interval 95\% }\end{array}$ & $\begin{array}{c}\text { Simple virilizing } \\
(\mathbf{n = 1 3})\end{array}$ & $\begin{array}{c}\text { Confidence } \\
\text { interval 95\% }\end{array}$ & $\boldsymbol{p}$ value & Reference values \\
\hline 170HP $(\mathrm{ng} / \mathrm{mL})$ & $209.4 \pm 196.7$ & $143.5-274.9$ & $56.3 \pm 43.5$ & $29.5-82.4$ & 0.00003 & 1 to $5 \mathrm{dL}=0.82-4.2$ \\
& & & & & 5 to $30 \mathrm{dL}=0.1-16.8$ \\
& & & & & 30 to $60 \mathrm{dL}=1.9-9.8$ \\
& & & & & $0.1-0.9$ \\
Androstenedione (ng/mL) & $15.6 \pm 30.1$ & $5.48-25.6$ & $6.7 \pm 2.9$ & $4.61-8.32$ & 0.14 & $<401$ \\
Testosterone (ng/dL) & $613.9 \pm 647.7$ & $397.8-829.8$ & $223.8 \pm 99.3$ & $163.7-283.9$ & 0.0005 & $132-146$ \\
Sodium (mEq/) & $127.2 \pm 9.2$ & $124.2-130.3$ & $135 \pm 3.9$ & $132-136.3$ & 0.0004 & $3.0-5.0$ \\
Potassium (mEq/) & $5.4 \pm 1.0$ & $5.02-5.73$ & $4.5 \pm 0.7$ & $4.07-5.0$ & 0.0008 & \\
\hline
\end{tabular}

170HP: 17-hydroxyprogesterone; dL: days of life.

${ }^{1}$ Except for boys younger than 1 year. 
$t$-test was applied to compare numerical variables from subjects with salt-wasting and simple-virilized forms. The level of significance was set at $5 \%(\mathrm{p}<0.05)$. Statistical analysis was conducted with SPSS, version 17.0 (Chicago: SPSS Inc.).

\section{RESULTS}

There were 884,742 live births registered in the State of Santa Catarina between January 2001 and December 2010. Of these, $748.395(89 \%)$ were screened for CAH by the NSP-DH/SC.

In total, 129 children with abnormal 17OHP levels on screening were referred for medical evaluation. Using the first kit (AutoDELFIA ${ }^{\circledR}$ ), 78 children who presented initially with elevated 17OHP levels showed normalization of these levels during follow-up. After change in kits $\left(\mathrm{GSP}^{\circledR}\right)$ and in cutoff level, only a single case of transitory elevation was observed.

There were 50 cases of $\mathrm{CAH}$, yielding an incidence of $1: 14.972$. Of these, 27 (54\%) were girls. The female to male ratio was $1: 1.7$. Mean birth weight was 3.213 $\pm 595 \mathrm{~g}$ and all children were born full-term. The saltwasting form was diagnosed in 37 children (74\%), 21 of which $(56.7 \%)$ were girls and $16(43.2 \%)$ were boys. In 24 children (48\%), the diagnosis of salt-wasting $\mathrm{CAH}$ was established by the presence of hyponatremia in the first medical evaluation. Serum levels of $17 \mathrm{OHP}$, androstenedione, testosterone, sodium and potassium in patients with salt-wasting and simple-virilizing forms on the first appointment are shown in table 2 .

Mean age at first sample collection in patients with confirmed $\mathrm{CAH}$ was $7.3 \pm 6.6$ days (median 5.5 days) and it did not differ between patients with and without the salt-wasting form of the disease $(\mathrm{p}=0.08)$. In patients with confirmed CAH mean 17OHP was $152.9 \pm$ $151.0 \mathrm{ng} / \mathrm{mL}$ (median $139.0 \mathrm{ng} / \mathrm{mL}$ - minimum 11.9 $\mathrm{ng} / \mathrm{mL}$ and maximum $788.0 \mathrm{ng} / \mathrm{mL}$ ). The minimum screening value of $17 \mathrm{OHP}$ in patients with salt-wasting $\mathrm{CAH}$ was $16.4 \mathrm{ng} / \mathrm{mL}$ and among those with simplevirilizing $\mathrm{CAH}, 11.9 \mathrm{ng} / \mathrm{mL}$. Mean age on treatment onset was 21.6 days. In patients with salt-wasting $\mathrm{CAH}$, mean age on treatment onset was 17.4 days and in those with simple-virilizing $\mathrm{CAH}$, it was 54.9 days.

The most frequent clinical manifestations in $\mathrm{CAH}$ - affected children were: virilized genitalia with nonpalpable gonads $(27 \%)$, clitoromegaly $(26 \%)$, genital hyperpigmentation $(25 \%)$, fused labioscrotal fold $(24 \%)$, enlarged phallus (23\%), dehydration (16\%), fused labia majora $(16 \%)$, vomit $(10 \%)$, diarrhea $(5 \%)$, anorexia $(5 \%)$ and fever $(5 \%)$. There were no cases of shock or death.

All children with virilized genitalia and nonpalpable gonads had a 46, XX karyotype. Table 3 shows the distribution of female children according to Prader stage and by clinical form. In three girls with Prader 5, there was an error in genre identification that required correction of the civil registration.

Table 3. Distribution of female children according to Prader stage and $\mathrm{CAH}$ forms

\begin{tabular}{ccc}
\hline Scale & $\begin{array}{c}\text { Salt wasting } \\
(\mathbf{n = 2 1 )}\end{array}$ & $\begin{array}{c}\text { Simple virilizing } \\
(\mathbf{n = 6}=\mathbf{6})\end{array}$ \\
\hline Prader 0 & 0 & $1(16.6 \%)$ \\
Prader I & 0 & $3(50 \%)$ \\
Prader II & $1(4.8 \%)$ & $1(16.6 \%)$ \\
Prader III & $4(19 \%)$ & $1(16.6 \%)$ \\
Prader IV & $13(62 \%)$ & 0 \\
Prader V & $3(14.2 \%)$ & 0 \\
\hline
\end{tabular}

Figure 1 shows the distribution of cases of $\mathrm{CAH}$ according to mesoregions of origin in the State of Santa Catarina. One child with $\mathrm{CAH}(2 \%)$ was born in the State of Minas Gerais, but CAH screening, diagnosis and treatment were all conducted in Santa Catarina.

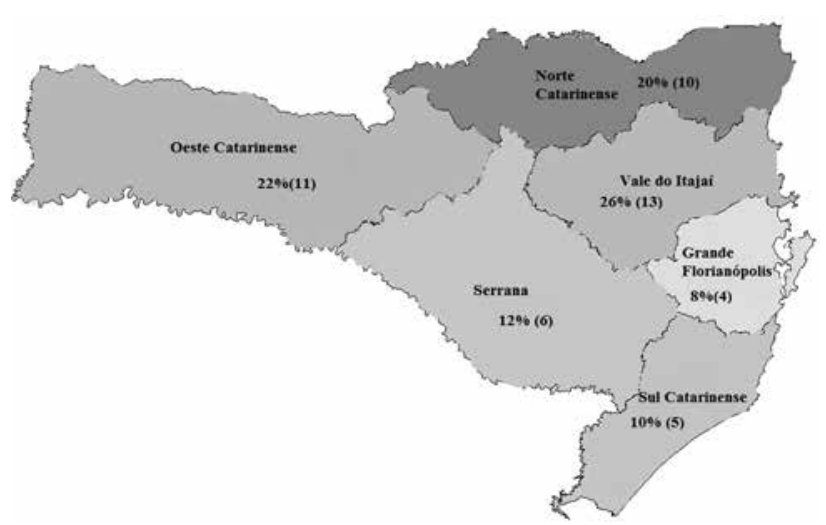

Figure 1. Distribution of cases of congenital adrenal hyperplasia (CAH) according to mesoregions in Santa Catarina.

\section{DISCUSSION}

The neonatal screening program for $\mathrm{CAH}$ was implemented in Santa Catarina in October 2000. During that year, no cases of $\mathrm{CAH}$ were diagnosed. The current study started in January 2001.

One of the aims of neonatal screening programs is universal coverage, which is, coverage of $100 \%$ of the live births. A 2005 study about neonatal screening programs in Latin America showed an overall coverage of 
49.3\%, including 64\% in Argentina, 70\% in Mexico, and the best results in Chile, Uruguay and Cuba, all with $99 \%$ (18). The coverage in the present study was $89 \%$, which is below ideal, but still, above the coverage in most Latin American countries (18).

It is possible that the coverage below $100 \%$ observed in our study may be related to lack of notification of screening results conducted in the private setting, such as clinics, maternity hospitals and laboratories. This may occur with any neonatal screening in Brazil, since the country has no legislation requiring notification of screening results or of cases diagnosed in private networks (19).

The incidence of $\mathrm{CAH}$ worldwide varies according to ethnic and geographic areas. In the state of Goiás in Brazil, the incidence was estimated in 1:10.325 (20) and in Minas Gerais in 1:19.939 (21). A study from Argentina reported an incidence of 1:8.900 (22). In Europe and North America, it is close to 1:15.000 and $1: 16.000$, reaching $1: 2.100$ in the French island of $\mathrm{La}$ Réunion and 1:280 among Yupik Eskimos in Alaska. In Japan, it is slightly lower, at 1:19.000 $(9,23,24)$. In Santa Catarina, it was 1:14.967, which is similar to results observed in Europe.

Sample collection for measurement of 17OHP should be performed after 48 hours of life. Screening programs recommend it to be performed between the $3^{\text {rd }}$ and $5^{\text {th }}$ day of life and to not exceed seven days (5). The NSP-SES/SC also adopts this recommendation, but in this study we observed that the average age at first sampling was 7.3 days, which is outside the recommended period. After this result, a new training was conducted, summoning all screening centers located in the State of Santa Catarina.

One of the limitations of screening programs for $\mathrm{CAH}$ is the high number of false-positive results (2427). Collection of samples before 48 hours of life can increase the rate of false positivity. Premature children and those with low weight have higher risk of false positive results in the neonatal screening test analyzed by the fluoroimmunoassay, method, which is the international standard $(5,28)$. Adoption of more precise cutoff levels for 17OHP, according to gestational age and birth weight, decrease the rate of false positivity and identify individuals at risk of adrenal crisis from those with mild forms of the disease $(28,29)$. Newborns with false-positive results have elevated levels of 17OHP, but are asymptomatic. Within the first months of live, 17OHP levels decrease spontaneously with subsequent measurements in these patients $(26,27)$. All newborns with $\mathrm{CAH}$ in our study were born at term and most had appropriate weight for gestational age, yielding a lower possibility of false positivity. However, until September 3, 2009, there were 78 cases with initial elevation in 17OHP which normalized without treatment during follow-up. With the change in kits and adjustment in cutoff level after September 4, 2009, the frequency of false positive results decreased and only one occurrence of transitory elevation was observed. We believe that this occurred due to the change in cutoff level with increased stratification for newborns with lower weight and to the new kit having lower cross reaction with other hormones such as 11-deoxycortisol, $17 \alpha$-pregnenolone, progesterone, and others.

It is very well recognized today that the age at diagnosis and treatment onset of children with $\mathrm{CAH}$ has decreased following establishment of neonatal screening programs. Studies demonstrate that the younger the age of the newborn on diagnosis, lower the duration of hospitalization and morbidity $(30,31)$. In Texas, the average age at diagnosis in the screened population was 12 days (32). In Santa Catarina, the average age identified was 21.6 days. However, we observed that the average age of treatment onset in patients with the salt-wasting form of the disease was even lower. Although this is still inappropriate considering that the main objective of the screening is to start treatment as early as possible in all cases, the approach adopted by the program identified with more effectiveness the newborns at higher risk of adrenal crisis. Since there was no difference in time of first sampling between $\mathrm{CAH}$ forms, the time for recall and execution of the second sample in cases in which the initial screening showed no levels for urgent medical assessment may have influenced these results and should be analyzed.

Girls with classic $\mathrm{CAH}$ have ambiguous genitalia at birth and may be registered and raised improperly as boys (8). We observed in our study that $6 \%$ of the children had improper gender identification, hence the importance of early diagnosis and confirmation with karyotype for early correction of the error in establishing the correct gender in affected girls.

The girls in this cohort showed variable degrees of virilization of the external genitalia. Regarding the type of $\mathrm{CAH}$, girls with the salt-wasting form of the disease showed a higher degree of virilization than those with the simple-virilizing form, which is consistent with the literature (6). 
According to the international experience in this type of screening, the salt-wasting form comprises $66-75 \%$ of all cases when compared with the simplevirilizing form, which ranges from 15 to $32 \%$ of the cases $(6,24)$. In this study, the salt-wasting form was responsible for $74 \%$ of cases, which is consistent with international statistics.

A study conducted in Texas observed that children with salt-wasting $\mathrm{CAH}$ presented more biochemical abnormalities when compared with those with the simplevirilizing form (32). This was also observed in our study in all tests but serum androstenedione, which did not differ significantly in patients with both of these forms of CAH. However, considering that the criteria used to define salt-wasting and simple-virilizing $\mathrm{CAH}$ was the presence of electrolyte disorder, the comparative analysis, particularly with respect to sodium and potassium, is subjected to bias.

One of the goals of screening for $210 \mathrm{OH}$ deficiency is to detect newborns with salt-wasting $\mathrm{CAH}$ before they present hypovolemic shock, endangering the life of the child. The mortality rate associated with a saltloss crisis in CAH is 4 to $10 \%$ (8). In our study, no cases of adrenal crisis or death were observed, despite the fact that 37 children presented the salt-wasting form of the disease. However, $65 \%$ of these already had hyponatremia at initial medical evaluation (Table 3 ), which probably would not have occurred had the diagnosis been established earlier. Anticipation of the diagnosis in boys with the simple-virilizing form is another goal of neonatal screening for $\mathrm{CAH}(32,33)$. In this study, this was accomplished in seven boys.

One of the most important aspects of a neonatal screening program is to ensure medical care and treatment to all children detected with the abnormality (29). All children diagnosed in this program received treatment at SEP-HIJG.

The coverage rate of the program by mesoregion of Santa Catarina was not analyzed, but we observed that children with $\mathrm{CAH}$ originated from all mesoregions, which suggests that the program has a broad scope.

The results of this study indicate that the NSP for $\mathrm{CAH}$ of the SES/SC needs to improve even further to diagnose the disease and start treatment at an earlier age. Strategies will be needed to streamline the several stages of the program, especially the age at which blood sample for $17 \mathrm{OHP}$ is first collected, which was the most critical point observed in our study. To improve this problem, the first sample should be collected between three and five days of life, as already recommended by the program.

Disclosure: no potential conflict of interest relevant to this article was reported.

\section{REFERENCES}

1. Krone N, Dhir V, Ivison HE, Arlt W. Congenital adrenal hyperplasia and P450 oxidoreductase deficiency. Clin Endocrinol (Oxf). 2007;66:162-72.

2. Merke DP, Bornstein SR. Congenital adrenal hyperplasia. Lancet. 2005;365:2125-36.

3. Forest MG. Recent advances in the diagnosis and management of congenital adrenal hyperplasia due to 21-hydroxylase deficiency. Hum Reprod Update. 2004;10(6):469-85.

4. Forest MG, Tardy V, Nicolino M, David M, MorelY. 21-Hydroxylase deficiency: an exemplary model of the contribution of molecular biology in the understanding and management of the disease. Ann Endocrinol (Paris). 2005;66(3):225-32.

5. Speiser PW, Azziz R, Baskin LS, Ghizzoni L, Hensle TW, Merke DP, et al. Congenital adrenal hyperplasia due to steroid 21-hydroxylase deficiency: an Endocrine Society clinical practice guideline. J Clin Endocrinol Metab. 2010;95(9):4133-60.

6. Working Group on Neonatal Screening of the European Society for Pediatric Endocrinology. Procedure for neonatal screening for congenital adrenal hyperplasia due to 21-hydroxylase deficiency. Horm Res. 2001;55:201-5.

7. Honour JW, TorresaniT. Evaluation of neonatal screening for congenital adrenal hyperplasia. Horm Res. 2001;55:206-11.

8. Nordenström A, Ahmed S, Jones J, Coleman M, Price DA, Clayton $\mathrm{PE}$, et al. Female preponderance in congenital adrenal hyperplasia due to CYP21 deficiency in England: implications for neonatal screening. Horm Res. 2005;63:22-8.

9. White PC. Neonatal screening for congenital adrenal hyperplasia. Nat Rev Endocrinol. 2009;5:490-8.

10. Cavarzere $P$, Camilot M, Teofoli F, Tatò L. Neonatal screening for congenital adrenal hyperplasia in North-Eastern Italy: a report three years into the program. Horm Res. 2005;63(4):180-6.

11. Grosse SD, Van Vliet G. How many deaths can be prevented by newborn screening forcongenital adrenal hyperplasia? Horm Res. 2007;67(6):284-91.

12. Pang S, Hotchkiss J, Drash AL, Levine LS, New MI. Microfilter paper method for 17 alpha-hydroxyprogesterone radioimmunoassay: its application for rapid screening for congenital adrenal hyperplasia. J Clin Endocrinol Metab. 1977;45:1003-8.

13. White PC, Speiser PW. Congenital adrenal hyperplasia due to 21-hydroxylase deficiency. Endocr Rev. 2000;21:245-91.

14. White PC, New MI. Genetic basis of endocrine disease: congenital adrenal hyperplasis due to 21-hydroxylase. J Clin Endocrinol Metab. 1992;74:6-11.

15. Thil'en A, Nordenström A, Hagenfeldt L, von Döbeln U, Guthenberg $C$, Larsson A. Benefits of neonatal screening for congenital adrenal hyperplasia (21-hydroxylase deficiency) in Sweden. Pediatrics. 1998;101(4):E11.

16. Banco de Dados do Sistema Único de Saúde. Nascidos Vivos Santa Catarina [Internet] 2012. Available at: http://tabnet.datasus. gov.br/cgi/deftohtm.exe?sinasc/cnv/nvSC.def. Accessed on: Jul 15, 2012.

17. Instituto Brasileiro de Geografia e Estatística. Censo Demográfico 2010 [Internet] 2012. Accessed on: Fev 11, 2012. Available at: http:// www.censo2010.ibge.gov.br. 
18. Borrajo G. Newborn screening in Latin America at the beginning of the 21st century. J Inherit Metab Dis. 2007;30(4):466-81.

19. Nascimento ML. Situação atual da triagem neonatal para hipotireoidismo congênito: críticas e perspectivas. Arq Bras Endocrinol Metab. 2011;55(8):528-33.

20. Silveira EL, dos Santos EP, Bachega TA, van der Linden Nader I, Gross JL, Elnecave RH. The actual incidence of congenital adrenal hyperplasia in Brazil may not be as high as inferred--an estimate based on a public neonatal screening program in the state of Goiás. J Pediatr Endocrinol Metab. 2008;21(5):455-60.

21. Barra CB, Silva IN, Pezzuti IL, Januário JN. Triagem neonatal para hiperplasia adrenal congênita. Rev Assoc Med Bras. 2012;58(4):459-64.

22. Gruneiro-Papendieck L, Chiesa A, Mendez V, Prieto L. Neonatal screening for congenital adrenal hyperplasia: experience and results in Argentina. J Clin Endocrinol Metab. 2008;21:73-8.

23. Pang S, Murphey W, Levine LS, Spence DA, Leon A, La Franchi S, et al. A pilot newborn screening for congenital adrenal hyperplasia in Alaska. J Clin Endocrinol Metab. 1982;55:413-20.

24. van der Kamp HJ, Wit JM. Neonatal screening for congenital adrenal hyperplasia. Eur J Endocrinol. 2004;151 Suppl 3:U71-5.

25. Gurian EA, Kinnamon DD, Henry JJ, Waisbren SE. Expanded newborn screening for biochemical disorders: the effect of a false-positive result. Pediatrics. 2006;117:1915-21.

26. Fernández $B H$, Fernández $M E$, Íñiguez ED, Zubicaray $B E$, Martín MBR, Arnao MDR, et al. Neonatal screening for congenital adre- nal hyperplasia: transitory elevation of 17-hydroxyprogesterone. J Clin Endocrinol Metab. 2011;24(3-4):155-62.

27. Alves $C A D$, Balesteri $\mathrm{V}$,Toralles MBP.Triagem neonatal para hiperplasia adrenal congênita: considerações sobre a elevação transitória da 17-hidroxiprogesterona. RBPS. 2006;19(4):203-8.

28. Hayashi G, Faure C, Brondi MF, Vallejos C, Soares D, Oliveira E, et al. Weight-adjusted neonatal $17 \mathrm{OH}$-progesterone cutoff levels improve the efficiency of newborn screening for congenital adrenal hyperplasia. Arq Bras Endocrinol Metab. 2011;55(8):632-7.

29. Van der Kamp HJ, Oudshoorn CG, Elvers BH, van Baarle M, Otten BJ, Wit JM, et al. Cutoff levels of 17-hydroxyprogesterone in neonatal screening for congenital adrenal hyperplasia should be based on gestational age rather than on birth weight. J Clin Endocrinol Metab. 2005;90:3904-7.

30. Balsamo A, Cacciari E, Piazzi S, Cassio A, Bozza D, Pirazzoli P, et al. Congenital adrenal hyperplasia: neonatal mass screening compared with clinical diagnosis only in the Emilia-Romagna region of Italy, 1980-1995. Pediatrics. 1996;98(3 Pt 1):362-7.

31. Brosnan PG, Brosnan CA, Kemp SF, Domek DB, Jelley DH, Blackett PR, et al. Effect of newborn screening for congenital adrenal hyperplasia. Arch Pediatr Adolesc Med. 1999;153:1272-8.

32. Therrell Jr BL, Berenbaum SA, Manter-Kapanke V, Simmank J, Korman K, Prentice L, et al. Results of screening 1.9 million Texas newborns for 21-hydroxylase-deficient congenital adrenal hyperplasia. Pediatrics. 1998;101:583-90.

33. New MI. Extensive clinical experience: nonclassical 21-hydroxylase deficiency. J Clin Endocrinol Metab. 2006;91:4205-14. 